\title{
KALIMAT TANYA DALAM BAHASA MELAYU DIALEK TAMIANG
}

\author{
Joko Hafrianto dan Mulyadi \\ Fakultas Ilmu Budaya, Universitas Sumatera Utara \\ email: jokohafrianto93@yahoo.co.id
}

\begin{abstract}
Abstrak
Penelitian ini merupakan penelitian kualitatif yang membahas struktur kalimat tanya dalam bahasa Melayu dialek Tamiang. Penelitian struktur kalimat tanya ini menggunakan teori x-bar sebagai kajian sintaksis generatif. Data penelitian ini berupa kalimat tanya mae 'apa', hapo 'siapa', kalo kapan', kek mano 'dimana', keno mae 'kenapa', dan gano 'bagaimana'. Data ini diperoleh dari hasil wawancara penutur asli bahasa Melayu dialek Tamiang dan data tersebut dianalisis dengan menggunakan metode agih. Hasil penelitian ini menunjukkan bahwa jenis kalimat tanya total dalam bahasa Melayu dialek Tamiang memerlukan jawaban "ya" atau "tidak", sedangkan jenis kalimat tanya parsial dalam bahasa Melayu dialek Tamiang memerlukan jawaban penjelasan atau keterangan.
\end{abstract}

Kata kunci: struktur kalimat, teori x-bar, bahasa Melayu dialek Tamiang

\section{INTERROGATIVE SENTENCES IN THE TAMIANG DIALECT OF MALAY}

\begin{abstract}
This is a qualitative study discussing the structures of interrogative sentences in the Tamiang dialect of Malay. The study on the structures of interrogative sentences uses the x-bar theory as a study of generative syntax. The data were in the form of sentences asking mae 'what', hapo 'who', kalo 'when', kek mano 'where', keno mae 'why', and gano 'how'. The data were collected through interviews with native speakers of the Tamiang dialect of Malaythe data were analyzed using the distributionalmethod. The results indicate that yes-no questions require a "yes" or "no" answer, while whquestions require explanation or information.
\end{abstract}

Keywords: sentence structures, $x$-bar theory, dialect Tamiang of Malay

\section{PENDAHULUAN}

Kalimat tanya (interogatif) merupakan bagian penting dalam kehidupan sehari-hari, karena sebagian besar komunikasi terjadi dalam bertanya dan menjawab pertanyaan. Sejauh ini kalimat tanya masih menjadi sebuah topik menarik untuk di teliti, terkhusus pada bahasa-bahasa daerah di Indonesia. Keragaman bahasa di Indonesia membuat ketertarikan tersendiri untuk mengetahui struktur kalimat tanya dalam satu bahasa daerah.

Bahasa Melayu mempunyai banyak dialek, salah satunya adalah bahasa Melayu dialek Tamiang yang umum- 
nya berada di Kabupaten Aceh Tamiang Provinsi Aceh. Bahasa Melayu dialek Tamiang yang berada di Kabupaten Aceh Tamiang, secara sintaksis (tata kalimat) memiliki kalimat tanya (Interogatif) seperti pada bahasa lainnya. Oleh karena itu, hal ini perlu dikaji akan kebenarannya.

Kalimat tanya berfungsi untuk menanyakan sesuatu. Kalimat tanya diucapkan dengan harapan akan mendapat respon berupa jawaban dari pendengar yang dituju. Berdasarkan bentuk jawaban yang diharapkan, kalimat tanya dapat dibedakan atas dua jenis, yaitu kalimat tanya yang menghendaki jawaban berupa penyangkalan atau pengiyaan (ya/tidak) bisa juga disebut kalimat tanya total dan kalimat tanya yang menghendaki jawaban berupa keterangan atau penjelasan bisa juga disebut kalimat tanya parsial. Dua jenis kalimat tanya ini juga terdapat dalam bahasa Melayu dialek Tamiang (Sulaiman, 1993:92).

Berbagai macam penelitian tentang kalimat tanya dilakukan oleh beberapa ahli. Dalam bahasa Melayu dialek Tamiang belum pernah dilakukan. Berikut penelitian-penelitian dalam kalimat tanya :

Penelitian pertama dilakukan oleh Pangi (2014) dalam tulisannya yang berjudul "Kalimat Tanya Dalam Bahasa Inggris dan Bahasa Loloda Suatu Analisis Kontrastif". Hasil penelitiannya menunjukkan bahawa terdiri dari persamaan dan perbedaan kalimat tanya seperti berikut: Persamaan kedua bahasa ini yaitu: Keduanya memiliki bentuk kalimat tanya ya atau tidak dan kalimat tanya mengunakan kata tanya seperti: why, what, where, when, who how (dalam bahasa Inggris), nango, moruoka, idoa, okia, kiaka, sokonoke (dalam bahasa Loloda). Namun, perbedaannya yaitu: Pada penempatan kata tanya. Bahasa Inggris, kata tanya ditempatkan pada awal kalimat. Bahasa Loloda, kata tanya ditempatkan pada awal dan akhir kalimat.

Penelitian selanjutnya membahas mengenai analisis kalimat interogatif pada novel garuda putih karya suparto brata yang dilakukan oleh Aprilliyanti (2014). Hasil penelitian Aprilliyanti menunjukkan bahawa pada novel Garuda Putih terdapat banyak variasi jenis kalimat interogatif, jenis kalimat interogatif tersebut meliputi kalimat interogatif keniscayaan ketidaktahuan, kalimat interogatif keniscayaan keraguraguan, dan kalimat interogatif keniscayaan pengesahan, kalimat interogatif informatif berpenanda partikel apa, kalimat interogatif informatif (KII) identif, KII kausatif, KII temporal, KII statif, KII pasif, KII lokatif, KII agentif, KII kuantitatif. Selain jenis kalimat interogatif, banyak juga variasi fungsi ataupun metapesan yang terdapat pada novel Garuda Putih karya Suparto Brata.

Penelitian yang berkaitan dengan kalimat tanya berikutnya yang banyak memberikan kontribusi terhadap artikel ini adalah penelitian yang dilakukan oleh Novy (2015) dalam tulisannya yang berjudul "Kalimat Interogatif Bahasa Melayu Dialek Langkat". Hasil penelitiannya menunjukkan bahwa analisis yang dilakukan memperoleh enam (6) ciri-ciri kalimat tanya bahasa Melayu dialek Langkat dan 21 struktur kalimat tanya dengan kata tanya, 13 struktur kalimat tanya berdasarkan fokus kalimat dan kata tanya, 8 struktur kalimat tanya tanpa kata tanya, 3 struk- 
tur kalimat tanya alternatif, 3 struktur kalimat tanya negatif, dan 4 struktur kalimat tanya embelan. Berdasarkan hasil penelitiannya, teori sintaksis yang dikemukakan oleh Alwi dkk (2003) pantas digunakan untuk meneliti kalimat tanya bahasa Melayu dialek Langkat khususnya di desa Secanggang. Kontribusi yang diberikan penelitian tersebut terhadap artikel ini adalah konsep kalimat tanya bahasa Melayu. Pada dasarnya bahasa Melayu di Indonesia memiliki persamaan konsep tata bahasanya.

Penelitian selanjutnya membahas tentang wh-fronting and the left periphery in mandarin yang dilakukan oleh Cheung (2014). Hasil Penelitian pada artikel ini secara mendalam telah diteliti sifat semantik dan sintaksis dari wh-fronting Konstruksi dalam bahasa Mandarin Mengambil pendekatan kartografi, yang berpendapat bahwa Topik dan Fokus kajian menempati dua proyeksi fungsional terpisah, kajian tersebut Telah menyelesaikan perdebatan lama mengenai status sintaksis wh-fronting Konstruksi dengan menunjukkan bahwa tatanan tersebut paling baik dianalisis sebagai tipe (IdentF), yaitu, (i) identifikasi lengkap dan (ii) kemampuan untuk menempati Posisi. Konstruksi dan bukan sebagai jenis struktur topik seperti kebanyakan penelitian sebelumnya. Diklaim meniru bukti dari efek konektivitas, kondisi lokalitas, kemampuan. Untuk melisensikan PG, dan pola distribusi dari penanda fokus She, saya berargumen Wh-fronting dan kata kerja dalam bahasa Mandarin.

Penelitian selanjutnya yang membahas tentang frasa preposisi bahasa indonesia: analisis x-bar yang dilakukan oleh Mulyadi (2010), artikel ini memberikan kontribusi yang sangat besar terhadap penyelesaian artikel ini. Artikel ini menampilkan struktur internal frasa preposisi '(FP) dalam bahasa Indonesia dengan menggunakan teori $\mathrm{X}$-bar. Hasil penelitian dalam artikel ini memperlihatkan bahwa sfruktur FP bahasa Indonesia dibentuk oleh komplemen, keterangan, dan spesifier. Kaidah pembentukannya dirumuskan sebagai berikut: (t) FP = P', Spes; $\mathrm{P}^{\prime}=\mathrm{P}^{\prime}$, Kornp, (z) Fp = p', Spes; p'= p', Ket; $p^{\prime}=$ P, Komp, (9 FP = P', Spes; FP = P', Spes; $\mathrm{P}^{\prime}=\mathrm{P}$, Ket; $\mathrm{y}=$ p, Komp. Kontribusi yang besar di berikan oleh artikel ini yaitu sama-sama menggunakan teori $\mathrm{X}$-Bar dalam menganalisis data.

Dari beberapa penelitian terdahulu di atas, dapat dilihat bahwa penelitian mengenai kalimat tanya dalam bahasa Melayu dialek Tamiang, masih jarang atau belum dilakukan. Dalam artikel ini, peneliti akan menganalisis struktur kalimat bahasa Melayu dialek Tamiang menggunakan teori yang mutahir yaitu teori x-bar. Maka dari itu, penelitian tentang kalimat tanya bahasa Melayu dialek Tamiang ini perlu dilakukan.

Penelitian dalam bahasa Melayu dialek Tamiang banyak mengangkat bidang fonologi, bidang morfologi, serta bidang ekonomi. Sedangkan, dalam bidang sintaksis bahasa Melayu dialek Tamiang tidak ditemukan, terbukti dengan kajian-kajian terdahulu di atas. Berlandaskan ketarangan pada kajian terdahulu di atas, tulisan ini mencoba menampilkan wajah baru dengan mengangkat judul 'Kalimat Tanya Bahasa Melayu Dialek Tamiang: Kajian Sintaksis Generatif'. Memberikan tampilan baru dalam menganalisis dengan menggunakan teori $\mathrm{x}$-bar sebagai acuan menganalisis, agar bahasa Melayu dialek Tamiang dapat diketahui oleh 
masyarakat luas dan dapat dilestarikan sebagai wujud keanekaragaman dialek bahasa di Indonesia.

Bahasa Melayu dialek Tamiang diasumsikan memiliki struktur kalimat yang serupa dengan bahasa Indonesia, baik dalam kalimat deklaratif maupun interogatif. Contoh 1 dan 2 adalah kalimat deklaratif memiliki struktur kalimat yang serupa atau bisa juga dikatakan sama.

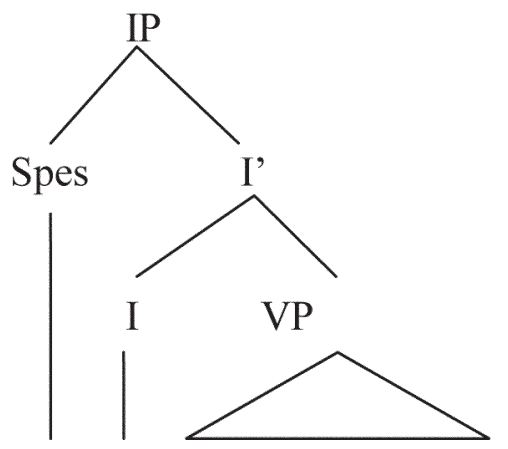

akak nak lalu kek taman isok

(Kakak akan pergi ke taman besok)
1. Akak nak lalu kek taman isok (bahasa Melayu dialek Tamiang)

2. Kakak akan pergi ke taman besok (bahasa Indonesia)

Contoh di atas menunjukkan struktur kalimat deklaratif dalama bahasa Melayu dialek Tamiang serupa atau bias dikatakan sama dengan bahasa Indonesia. Dengan demikian, jika kita menganalisisnya dengan menggunakan teori $\mathrm{x}$-bar, maka jelas akan tampak struktur kalimat yang serupa atau sama. Seperti:

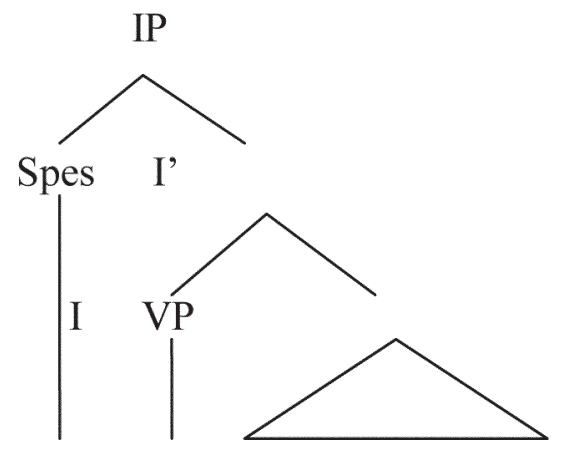

Kakak akan pergi ke taman besok

\section{Gambar 1. Struktur kalimat deklaratif bahasa melayu dialek Tamiang dan bahasa Indonesia}

Persamaan struktur kalimat deklaratifpada contoh di atas menjelaskan bahwa struktur kalimat dalam bahasa Melayu dialek Tamiang serupa atau sama dengan struktur kalimat bahasa Indonesia. Begitu juga struktur pada kalimat interogatif juga memiliki struktur yang sama. Seperti contoh 3 dan 4 di bawah ini:

3. Dimana kamu jemput ayah besok? (bahasa Indonesia)

4. Kekmano engko jemput abah isok? (bahasa Melayu dialek Tamiang)

Kedua contoh di atas dapat dilihat bahwa kalimat interogatif juga memi- liki struktur kalimat yang sama. Oleh sebab itu, jika di analisis dengan teori $\mathrm{x}$-bar maka akan menunjukkan bentuk yang sama dengan kalimat deklaratif. Namun, seperti penjelasan sebelumnya pada kalimat interogatif terdapat dua jenis kalimat tanya yaitu kalimat tanya total dan kalimat tanya parsial. Contoh di atas merupakan kalimat interogatif dalam bentuk kalimat tanya parsial. Kata tanya dalam bahasa Melayu dialek Tamiang adalah 'mae' (apa), 'hapo' (siapa), 'kalo' (kapan), 'kekmano' (dimana), 'keno mae' (kenapa), 'gano' (bagaimana). Sedangkan kalimat tanya 
total dalam bahasa Melayu dialek Tamiang adalah kalimat yang digabungkan dengan akhiran -kah seperti: 'betolke' (benarkah), 'endakke' (maukah), 'sukoke' (sukakah), 'udahke' (sudahkah), 'edapke' (enakkah), 'adoke' (adakah), dan sebagainya dalam bahasa Indonesia.

Paparan di atas menunjukkan bahwa pada bahasa Melayu dialek Tamiang juga memiliki kata tanya dan membentuk kalimat tanya. Sebab itu peneliti ingin mengulas lebih dalam secara saksama dengan menggunakan teori X-Bar yang dikemukakan oleh Noam Chomsky, seorang ilmuwan yang mengemukakan bahwa frasa yang mempunyai struktur yang sama harus dikaji secara eksplisit. Gagasan dalam teori X-bar ialah bahwa di dalam struktur internal frasa yang berbeda dalam sebuah bahasa ditemukan pola yang sama pada setiap struktur (Sells, 1985:27) dalam (Mulyadi, 2010:3). Penelitian ini membahas struktur kalimat tanya dalam bahasa Melayu dialek Tamiang.

\section{METODE PENELITIAN}

Kajian ini merupakan penelitian kualitatif, data yang dikumpulkan adalah berupa kata-kata dan bukan angkaangkan dengan cara deskriptif dalam bentuk kata-kata dan bahasa pada suatu konteks khusus yang alamiah dan dengan memanfaatkan berbagai metode alamiah (Moleong, 2014 : 6).

Seluruh data dijaring menggunakan metode simak dan didukung oleh teknik catat. Seluruh data kalimat tanya dianalisis menggunakan metode agih yang merupakan bagian dari bahasa itu sendiri justru menjadi alat penentunya. Hal ini merupakan metode yang tepat dalam menganalisis bahasa (Sudaryanto, 2015:18).

Penelitian ini dimulai dengan mengumpulkan data. Data verbal yang akan digunakan dalam penelitian ini, dikumpulkan melalui metode observasi dan wawancara. Dalam metode observasi, data direkam dan dicatat dari pengguna bahasa sehari-hari. Dalam metode wawancara, subjek ditanya tentang bagaimana menanyakan sesuatu atau cara bertanya secara interogatif dalam bahasa Melayu dialek Tamiang. Subjek adalah orang yang berbahasa $\mathrm{Me}$ layu dialek Tamiang dalam kehidupan sehari-hari. Jawaban dari subjek juga direkam dan dicatat.

Sumber data dalam penelitian ini adalah penutur bahasa Melayu dialek Tamiang yang berada di kecamatan Karang Baru Aceh Tamiang. dalam hal ini informan berjumlah 3 orang laki-laki maupun perempuan. Mereka berusia 50-60 tahun dan memiliki pengetahuan berbahasa Tamiang yang baik.

Data dalam penelitian ini berupa kata-kata kalimat tanya dalam bahasa Melayu dialek Tamiang. Data di peroleh dengan cara wawancara secara langsung dengan ketiga (3) informan yang terpilih. Data yang dikumpulkan dari hasil wawancara adalah kalimat tanya (interogatif) dalama bahasa $\mathrm{Me}$ layu dialek Tamiang. Terdapat dua jenis kalimat tanya (interogatif), yaitu kalimat tanya total dan kalimat tanya parsial. Berikut adalah tabel data yang 
Tabel 1. Kalimat tanya parsial bahasa Melayu dialek Tamiang

\begin{tabular}{ll}
\hline \multicolumn{1}{c}{ Bahasa Melayu Dialek Tamiang } & \multicolumn{1}{c}{ Bahasa Indonesia } \\
\hline Hapo yang akak jemput kek sekolah? & Siapa yang kakak jemput di sekolah? \\
Kek mano akak jemtut dio? & Dimana kakak menjemput dia? \\
Mae yang emo beli? & Apa yang ibu beli? \\
Kalo emo tijak? & Kapan ibu akan datang? \\
Akak jemput hapo? & Kakak menjemput siapa? \\
Emo beli mae? & Ibu beli apa? \\
\hline
\end{tabular}

\section{Tabel 2. Kalimat tanya total bahasa Melayu dialek Tamiang}

\begin{tabular}{ll}
\hline \multicolumn{1}{c}{ Bahasa Melayu Dialek Tamiang } & \multicolumn{1}{c}{ Bahasa Indonesia } \\
\hline Betolke emo tijak kek Medan isok? & Benarkah ibu datang ke Medan besok? \\
Endakke engko ikut kek pante isok? & Maukah engkau ikut ke pantai besok? \\
Sukoke adik makan ikan? & Sukakah adik makan ikan? \\
Udahke engko basoh pinggan ne? & Sudahkah engkau cuci piring ini? \\
Edapke ghaso masakan ne? & Enakkah rasa masakan ini? \\
Adoke bahan-bahan untuk bueknye? & Adakah bahan-bahan untuk membuatnya? \\
\hline
\end{tabular}

dikumpulkan, adalah sebagai berikut:

Setelah data dikumpulkan, data tersebut dibagi berdasarkan pada jenis penggunaannya. Kemudian dianalisis dengan metode distribusional dan teknik substitusional. Dalam tulisan ini, teknik subtitusi digunakan untuk mengidentifikasi fungsi leksikal dan gramatikal dari kata tanya.

a. Akak menjemput adik kek sekolah

Kakak menjemput adik di sekolah $\begin{array}{llll}\text { NP } & V & \text { NP } & \text { PP }\end{array}$

(kakak menjemput adik di sekolah)

b. Akak menjemput hapo kek sekolah

Kakak menjemput siapa di sekolah $\begin{array}{llll}N P & V & N P & P P\end{array}$

(kakak menjemput siapa di sekolah)

NP "adik" diganti menjadi "hapo" yang berarti "siapa" karena "adik" merupakan kata benda. Pada tahap ini dapat dilihat bahawa kata tanya "hapo" memiliki fungsi leksikal sebagai kata benda, oleh karena itu, kata tanya "hapo" dapat menduduki posisi yang didominasi oleh specifier.

Tahap ini, teori X-bar digunakan untuk menganalisis dan mengidentifikasi data karena merupaka teori universal yang dapat digunakan bahasa apa pun yang ada di dunia ini. Teori $\mathrm{X}$ bar dengan menggunakan diagram pohon dapat menjelaskan apakah dalam frasa atau klausa dapat memberikan fungsi yang jelas dari setiap katagori kata. Dan juga, teori X-bar belum pernah digunakan dalam menganalisis kalimat tanya (interogatif) dalam bahasa Melayu dialek Tamiang.

\section{HASIL DAN PEMBAHASAN Hasil}

Keraf (1991:2014) menyatakan kalimat tanya (interogatif) terbagi dalam tiga katagori. Pertama, kalimat tanya total (total question) yang terdiri dari kata tanya "apakah" atau akhiran -kah. Kedua, kalimat tanya parsial (parsial question) yang terdiri dari 
kata tanya (siapa, apa, dimana, kapan, mengapa, bagaimana). Ketiga, kalimat tanya retoris (rhetorical question) berarti kalimat interogatif yang tidak memerlukan jawaban, biasanya digunakan dalam gaya bahasa, seperti dalam pidato atau percakapan sehingga pendengar mengetahui jawaban dari pertanyaan.

Semenetara itu, (Sulaiman, 1993: 92) menambahkan kalimat tanya (interogatif) di bahasa Melayu dialek Tamiang dapat dibangun dengan dua jenis, yaitu kalimat tanya yang menghendaki jawaban berupa penyangkalan atau pengiyaan (ya/tidak) bisa juga disebut kaliamat tanya total dan kalimat tanya yang menghendaki jawaban berupa keterangan atau penjelasan bisa juga disebut kalimat tanya parsial. Kata tanya parsial dalam bahasa Melayu dialek Tamiang adalah 'mae' (apa), 'hapo' (siapa), 'kalo' (kapan), 'kekmano' (dimana), 'keno mae' (kenapa), 'gano' (bagaimana). Sedangkan kaliamat tanya total dalam bahasa Melayu dialek Tamiang adalah kalimat yang digabungkan dengan akhiran -kah se-perti: 'betolke' (benarkah), 'endakke' (maukah), 'sukoke' (sukakah), 'udahke' (sudahkah), 'edapke' (enakkah), 'adoke' (adakah), dan sebagainya dalam bahasa Indonesia.

Kalimat interogatif diakhiri dengan tanda tanya (?) pada bahasa tulis dan pada bahasa lisan dengan suara naik, terutama jika tidak ada kata tanya atau suara turun. Bentuk kalimat iterogatif biasanya digunakan untuk meminta (1) jawaban " ya " atau " tidak", atau (2) informasi mengenai sesuatu atau seseorang dari lawan bicara atau pembaca (Alwi, 2003:358) dalam (Novi, 2015:11).
Chaer ( 2011: 350-356) menjelaskan mengenai kalimat tanya adalah kalimat yang isinya mengharapkan reaksi atau jawaban berupa pengakuan, keterangan, alasan, pendapat dari pihak pendengar atau pembaca. Dilihat dari reaksi jawaban yang diharapakan dibedakan adanya:

1. Kalimat tanya yang meminta pengakuan atau jawaban: ya - tidak, atau ya - bukan

2. Kalimat tanya yang meminta keterangan mengenai salah satu unsur kalimat.

3. Kalimat tanya yang meminta alasan.

4. Kalimat tanya yang meminta pendapat atau buah pikiran orang lain.

5. Kalimat tanya yang menyuguhkan. Hampir di seluruh buku teks modern sintaksis membahasa teori $\mathrm{x}$-bar, untuk mengidentifikasi fitur sintaksis. Teori x-bar pertama kali dipelopori oleh Noam Chomsky pada tahun 1970 dan dikembangkan lebih lanjut oleh Ray Jackendoff pada tahun 1977. Cilicover (1997:134) menyatakan bahwa teori xbar adalah teori struktur frasa. Artinya, teori $\mathrm{x}$-bar ini adalah teori tentang ungkapan yang mungkin terjadi dalam bahasa biasa yang alami.

Sebelum kemunculan teori X-bar struktur frasa, hubungan hierarkis di antara kategori sintaksis diatur melalui sebuah kaidah, yang dinamakan kaidah struktur frasa. Dalam kaidah ini terdapat dua tipe kategori: pertama, kategori leksikal seperti verba, nomina, adjektiva, dan preposisi; dan kedua, kategori frasa seperti frasa verba, frasa nomina, frasa adjektiva, dan frasa preposisi. $\mathrm{Pa}$ da masa itu belum disinggung adanya sebuah kategori yang lebih besar dari kategori leksikal, tetapi lebih kecil dari 
kategori frasa, seperti di antara nomina dan frasa nomina atau di antara verba dan frasa verba. Faktanya, melalui sejumlah tes sintaktis seperti substitusi, koordinasi, atau pronominalisasi terbukti adanya kategori tersebut. Inilah yang disebut kategori antara (intermediate cotegory) dan menjadi dasar munculnya teori X-bar Culicover (1997:134) dalam Mulyadi (2010:3).

Mulyadi (2010:4) mengungkapkan Lebih lanjut, teori X-bar mengenal dua tataran proyeksi. Kedua proyeksi tersebut direpresentasikan pada level sintaktis. Jika sebuah kategori leksikal dibentuk oleh komplemen, keterangan, dan spesifier, komplemen yang berkombinasi dengan $\mathrm{X}$ akan membentuk proyeksi $\mathrm{X}$-bar; keterangan yang berkombinasi dengan X-bar akan membentuk proyeksi X-bar lebih tinggi; spesifier yang berkombinasi dengan X-bar yang tebih tinggi akan membentuk proyeksi maksimal frasa X. Jadi, kategori bar adalah proyeksi $\mathrm{X}$ dan frasa dengan bar tertinggi ialah proyeksi maksimal dari kategori X.

Relasi hierarkis struktur frasa itu digambarkan di bawah. Dalam hal ini, simbol X merupakan pengganti kategori leksikal, apakah N, V A, atau P sementara tanda titik-titik ( ...) di sebelah kiri dan kanan adalah pengisi komplemen, keterangan, atau spesifier.<smiles></smiles>

Melalui skema (1), tiap-tiap kategori tidak perlu direpresentasikan tersendiri karena sudah mencakup generatisasi kaidah yang ada. Cara ini tebih me- nyederhanakan struktur frasa tersebut. Dalam urutan linear, bila skema (1) dilengkapi dengan komplemen, keterangan, dan spesifier, strukturnya akan tergambar dalam kaidah berikut.

2. a. X'- YP; $X^{\prime}$

b. $\mathrm{x}^{\prime}-\mathrm{x}^{\prime} ; \mathrm{ZP}$

c. $\mathrm{X}^{\prime}-\mathrm{X} ; \mathrm{WP}$

Keterangan:

$$
\begin{array}{ll}
\mathrm{YP} & =\text { Spesifier } \\
\mathrm{ZP} & =\text { Keterangan } \\
\mathrm{WP} & =\text { Komplemen }
\end{array}
$$

Simput $\mathrm{X}^{\prime}$ bisa iteratif.

Penting dicatat bahwa realisasi dari skema di atas bergantung pada susunan konstituen dari bahasa yang dikaji, misalnya datam bahasa Inggris preposisi mendahului komplemen. Dengan susunan seperti dalam skema X-bar terletak di sebelah kanan (Haegeman, 1992:94). Sebaliknya, dalam bahasa Jepang komplemen justru mendahului preposisi dan kategori ini diacu sebagai posposisi. Komplemennya digambarkan di sebelah kiri dari skema X-bar. Jelaslah bahwa meskipun dijumpai perbedaan susunan kata pada bahasa-bahasa di dunia, perbedaan itu tetap dapat dijelaskan datam teori X-bar (Tarigan, 1984:51 dalam Mulyadi, 2010:5).

\section{Pembahasan \\ Fungsi Gramatikal dari Kata Tanya}

Kalimat tanya (interogatif) bahasa Melayu dialek Tamiang dibangun oleh Spicifier, Complemen, dan Adverbia. Specifier adalah struktur internal yang harus di tempati oleh NP, dan berkombinasi menjadi I' dan membentuk IP. Complemen adalah struktur internal yang dapat di tempati oleh $\mathrm{PP}$, atau NP. PP atau NP berkombinasi ke V dan membentuk V' pertama. Adverbial adalah struktur internal yang dapat di 
tempati oleh PP atau NP, dan berkombinasi ke V' pertama membentuk V' kedua.

Seperti yang dipaparkan di atas, kalimat tanya (interogatif) di analisis dengan menggunakan teknik subtitusi dan menggunakan teori X-bar untuk melihat stuktur kalimat tanya (interogatif) dan katagori leksikal complemen, keterangan, dan specifier. Pertama, akan dijelaskan fungsi gramatikal kata tanya, dan data yang dikumpulkan didasarkan pada jenis penggunaannya. Berikut adalah representasi data:

7. Hapo yang akak jemput kek sekolah?
8. Akak jemput hapo?

9. Mae yang emo beli?

10. Emo beli mae?

11. Udahke engko cuci pinggan ne?

12. Sukoke adik makan ikan?

Pembahasan kalimat tanya (interogatif) dalam bahasa Melayu dialek Tamiang adalah kalimat tanya parsial dan kalimat tanya total. Pertama, kalimat tanya parsial, diawali dengan struktur kalimat tanya parsial, berubah dari kalimat deklaratif menjadi kalimat tanya (interogatif) pada struktur kalimatnya. Berikut analisis contoh (7a), (7b), dan (7c) dalah sebagai berikut:

(7a). Akak menjemput adik kek sekolah.

(7b). Akak menjemput hapo kek sekolah.

(7c). Hapo yang akak jemput kek sekolah?

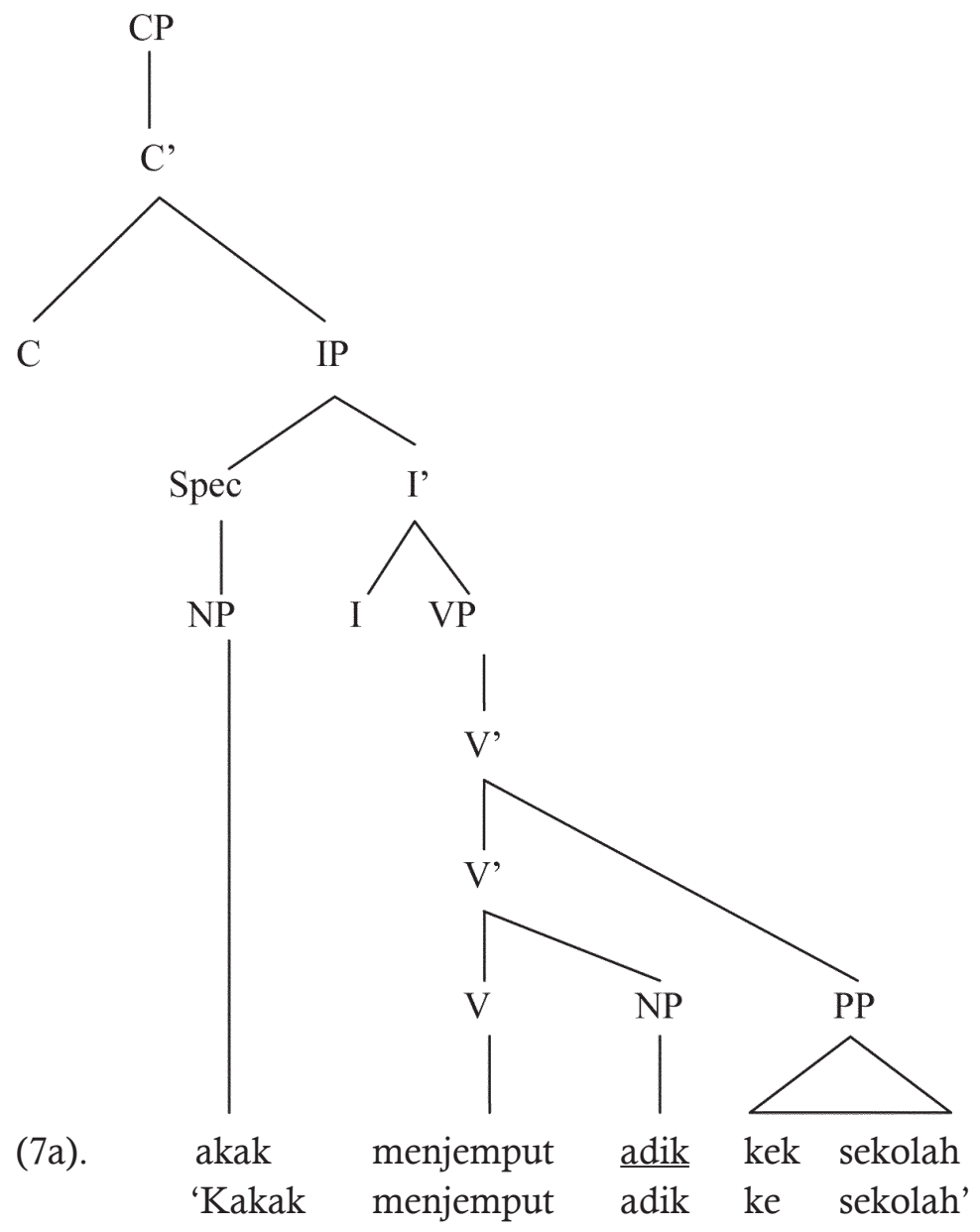

Gambar 2. Bentuk kalimat aktif 


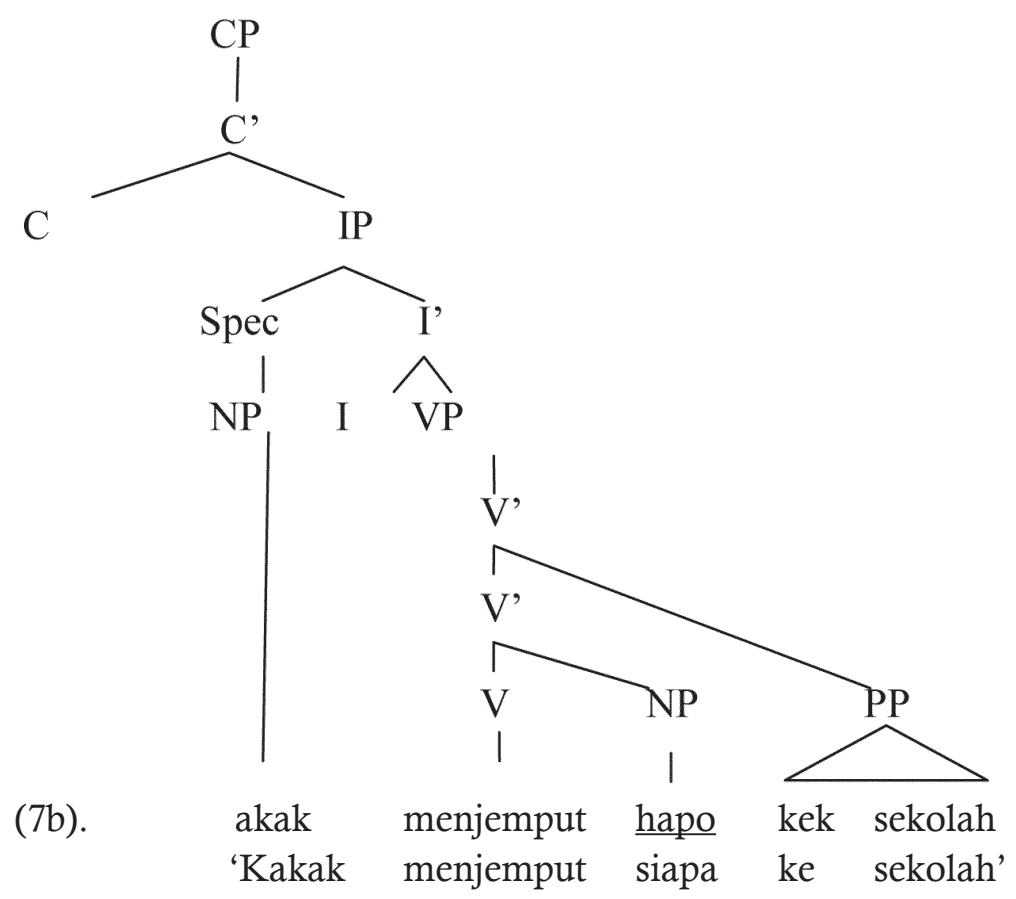

\section{Gambar 3. Bentuk kalimat tanya}

Struktur perpindahan kata tanya dengan menggunakan diagram pohon pada contoh (7a), (7b), dan (7c), adalah sebagai berikut:

Pada (7a), NP "adik" adalah complemen VP karena berkombinasi dengan $\mathrm{V}$ dan membentuk V' pertama. PP adalah adverb dari VP karena berkombinasi dengan V' pertama dan membentuk V' kedua, dan kemudian langsung membentuk VP. VP adalah complemen IP karena berkombinasi dengan I dan membentuk I'. NP " akak" adalah Specifier karena berkombinasi dengan I' pertama dan membentuk IP. Specifier harus berupa NP.

Pada (7b), struktur kalimatnya sama dengan (7a). tetapi, NP "adik" diganti menjadi "hapo" yang berarti "siapa" karena "adik" merupakan kata benda. Kata tanya (siapa, bagaimana, ka- pan, mengapa, siapa, dan bagaimana) berfungsi sebagai NP (Kridalaksana, 1994).

Pada (7c), posisi NP "hapo" bergerak dan meninggalkan jejak (ti). Bergerak pindah ke posisi terdepan dan berfungsj/sebagai Specifier, karena kata pertanyaan berfungsi sebagai NP.

'Sentuk lait' dari kata tanya parsial adalah contoh $(\&)$ dan (10) sebagai berikut:

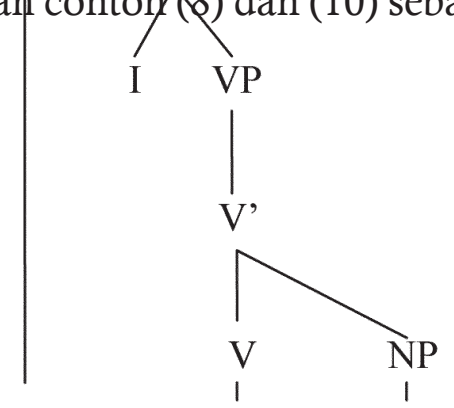

(8) Akak jemput hapo? 


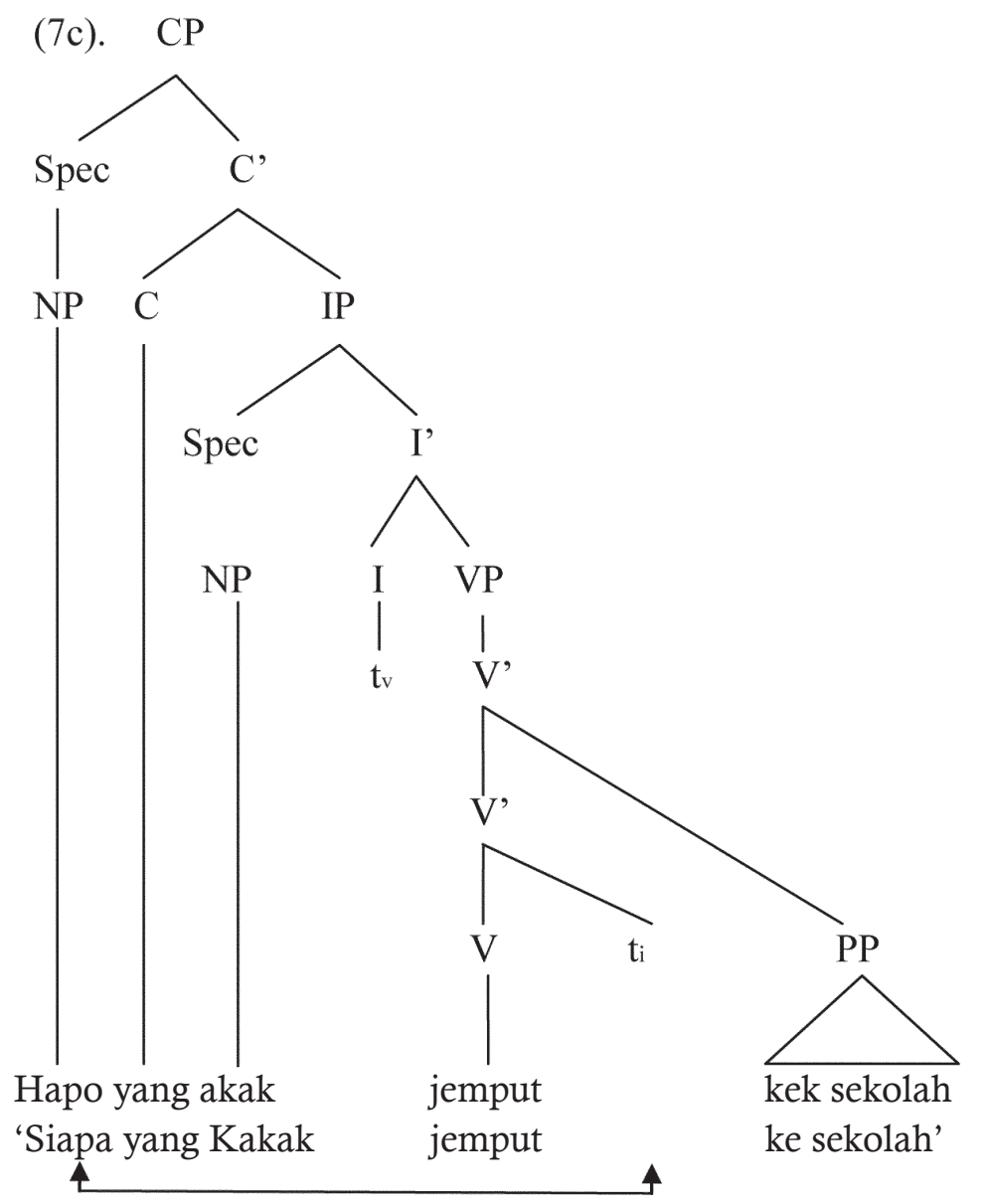

Gambar 4. Bentuk perpindahan kalimat tanya

$\begin{array}{cll}\text { 'Kakak } & \text { jemput } & \text { siapa?' } \\ \text { (10) Emo } & \text { beli } & \text { mae? } \\ \text { 'Ibu } & \text { beli } & \text { apa?' }\end{array}$

\section{Gambar 5. Bentuk lain kalimat tanya parsial}

Contoh (8) dan (10), NP adalah complemen VP karena berkombinasi dengan $\mathrm{V}$ dan membentuk $\mathrm{V}$ ' pertama. VP adalah complemen IP, karena berkombinasi dengan I dan membentuk I'. Kata "akak" dan "emo" berfungsi sebagai Specifier karena berkombinasi dengan I' dan membentuk IP. Kata tanya "hapo" dan "mae" pada contoh (8) dan (10) berfungsi sebagai complemen.

Analisis (7c), (8), dan (10) di atas, dapat dilihat bahwa kata tanya "siapa", dan "apa" dapat berfungsi baik sebagai specifier dan complemen tergantung pada posisinya. Jika kata tanya di letakkan di depan, maka akan difungsikan sebagai specifier. Karena berkombinasi dengan C' dan membentuk proyeksi maksimal CP. Tapi, saat kata tanya di letakkan di posisi akhir, maka akan difungsukan sebagai complemen. Karena berkombinasi dengan $\mathrm{V}$ dan membentuk V' pertama.

Kata tanya dalam bahasa Melayu dialek Tamiang adalah 'mae' (apa), 'hapo' (siapa), 'kalo' (kapan), 'kekmano' (dimana), 'keno mae' (kenapa), 'gano' (bagaimana) berfungsi sama seperti penjelasan di atas. Karena fungsi 
leksikal mereka adalah sebagai kata benda (Kridalaksana, 1994). Seperti yang di paparkan sebelumnya bahwa kalimat tanya (interogatif) dalam bahasa Melayu dialek Tamiang dapat di bangun dengan dua jenis, kalimat tanya parsial dan kalimat tanya total, seperti yang dijelaskan di atas. Dalam kata tanya total, kata tanya yang digunakan untuk menunjukkan itu adalah sebuah pertanyaan adalah dengan menambahkan akhiran -kah pada tiap-tiap katanya, seperti apakah, benarkah, sukakah, maukah, dan kata lainya dalam bahasa Indonesia. lihatlah contoh di bawah ini:
11. a. Benarkah ibu datang ke Medan besok?

b. Betolke emo tijak kek Medan isok?

12. a. Maukah engkau ikut ke pantai besok?

b. Endakke engko ikut kek pante isok?

13. a. Sukakah adik makan ikan?

b. Sukoke adik makan ikan?

14. a. Sudahkah engkau cuci piring ini?

b. Udahke engko basoh pinggan ne?

15. a. Enakkah rasa makanan ini?

b. Edapke ghaso masakan ne?

Contoh di atas dapat dilihat bahwa kata tanya yang digunakan untuk menunjukkan itu adalah sebuah pertanyaan adalah dengan menambahkan

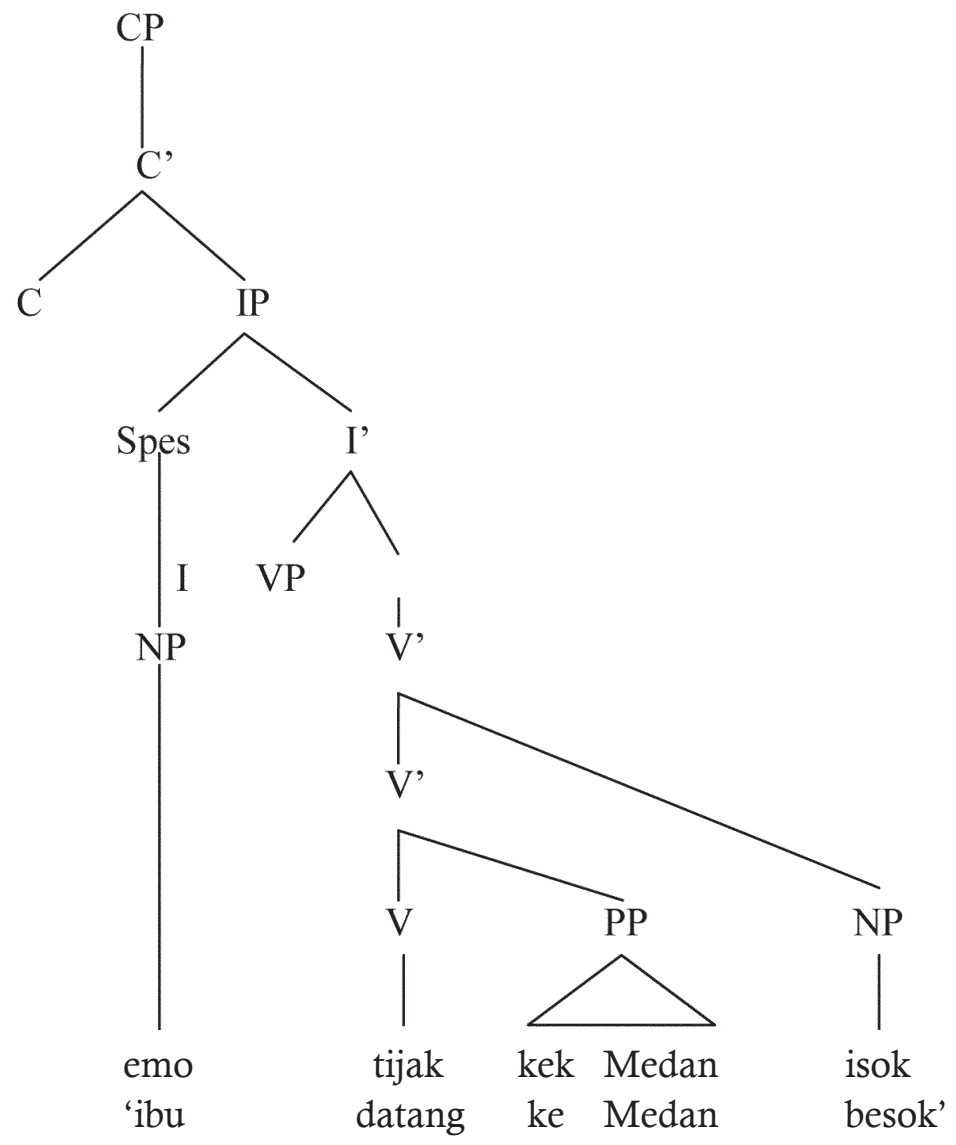

Gambar 6. Struktur kalimat pertanyaan 


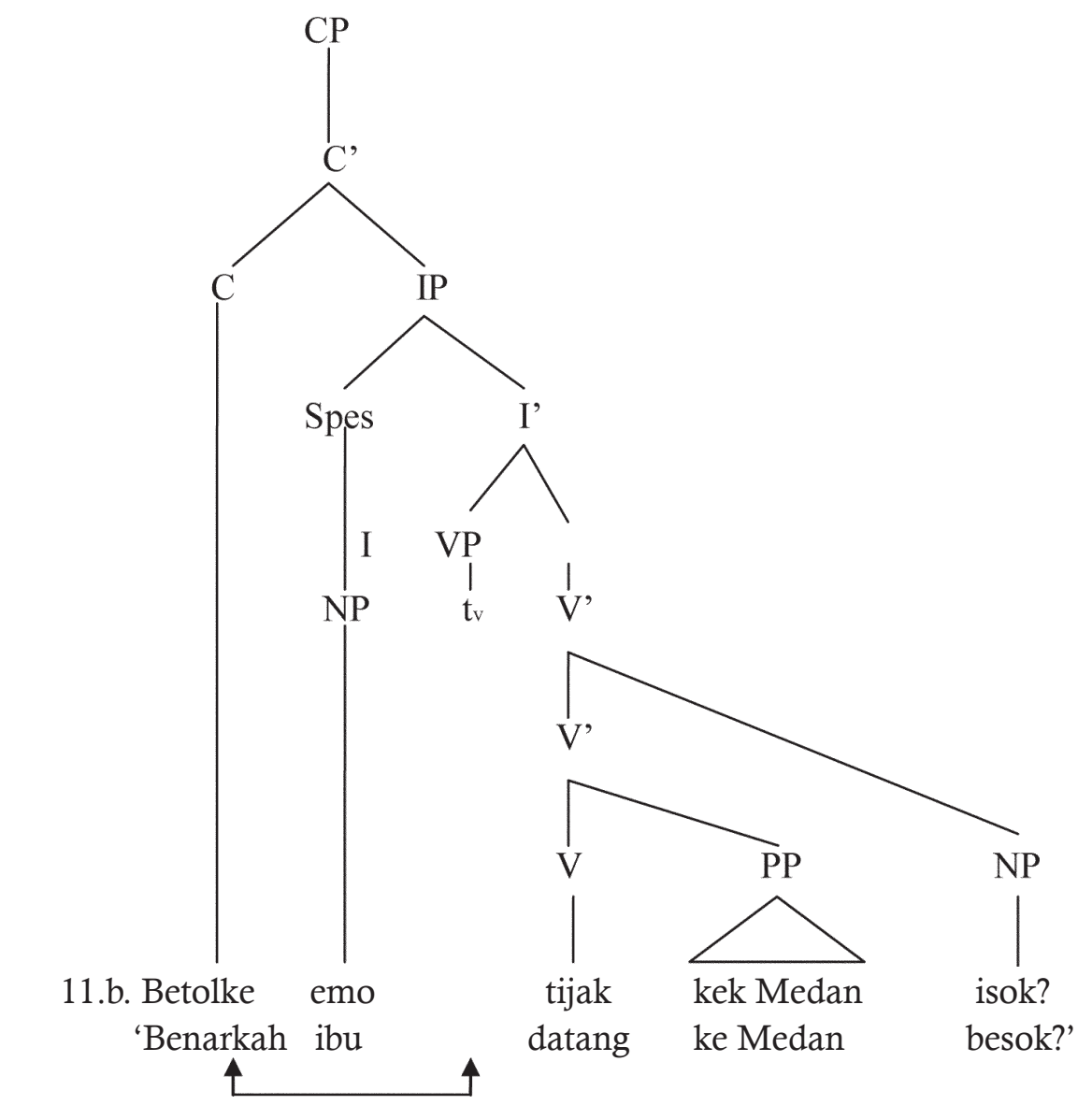

Gambar 7. Perpindahan kalimat tanya dan penambahan partikel -kah

akhiran -kah pada tiap-tiap katanya dalam bahasa Indonesia. Struktur kalimat pertanyaannya akan dijelasakan sebagai berikut:

Diagram pohon di atas menjelaskan bahwa PP merupakan complemen karena berkombinasi dengan $\mathrm{V}$ membentuk V' pertama. NP “isok" adalah adverb dari VP karena berkombinasi dengan $V^{\prime}$ pertama membentuk V' kedua, dan kemudian langsung membentuk VP. VP adalah complemen dari IP karena berkombinasi dengan I dan membentuk I'. NP "emo"adalah specifier karena berkombinasi dengan I' dan membentuk IP. Specifier harus berupa NP. Dalam bentuk kata tanya total,
"I" bergerak meninggalkan jejak (tv), diganti dengan kata "betolke" yang berfungsi sebagai complemen. Kata "betolke" diindikasikan sebagai modal atau auxiliary dalam bahasa inggris, sama seperti will (akan).

\section{Katagori Leksikal Specifier, Complemen, dan Adverb}

Seperti paparan sebelumnya di atas, bahwa kalimat tanya (interogatif) dalam bahasa Melayu dialek Tamiang dibangun oleh specifier, complemen, dan adverb. Katagori leksikal yang dapat menempati posisi specifier adalah NP. Lihat contoh (7a.) dan (7c.) berikut:

(7) a. Akak jemput adik kek sekolah. Kakak menjemput adik 


$\begin{array}{lll}\text { NP } & \text { V NP } \\ \text { Spes } & & \\ \frac{\text { di sekolah. }}{\mathrm{PP}} & & \end{array}$

(kakak menjemput adik di sekolah)

(7) c. hapo yang akak jemput kek sekolah?

Siapa yang kakak jemput

NP Aux NP V

Spes

di sekolah?

$\mathrm{PP}$

(siapa yang kakak jemput di sekolah?)

Katagori leksikal yang dapat menempati posisi complemen adalah auxiliary atau kata tambah, PP, atau NP. Seperti contoh (7a), (11), dan (11b) berikut:

(7) a. Akak jemput adik kek sekolah.

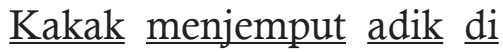
$\begin{array}{llll}\text { NP } & V & \text { NP } & C\end{array}$ sekolah. $\mathrm{PP}$

(kakak menjemput adik di sekolah)

(11). emo tijak kek Medan isok ibu datang ke Medan besok

NP V PP C NP

(ibu datang ke Medan besok)

(11) b. Betolke emo tijak kek

Benarkah ibu datang ke

Aux NP V C

Medan isok?

Medan besok?

PP NP

(benarkah ibu datang ke Medan besok?)
Katagori yang dapat menduduki posisi adverb adalah PP atau NP. Seperti contoh (7a.) dan (11) di bawah berikut:

(7) a. Akakjemput adik kek

Kakak menjemput adik di $\begin{array}{lll}\text { NP } & V & \text { NP Adv }\end{array}$ sekolah.

sekolah.

PP

(kakak menjemput adik di sekolah)

(11). emo tijak kek Medan isok

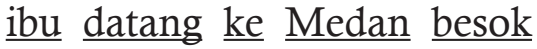

NP V Adv NP PP

(ibu datang ke Medan besok)

\section{SIMPULAN}

Struktur internal kalimat tanya (interogatif) bahasa Melayu dialek Tamiang di bangun oleh specifier, complemen, dan adverbia. Adapun specifier di duduki oleh NP, complemen di duduki oleh auxiliary, PP, atau NP, sedangkan adverb dapat di duduki oleh PP atau NP.

Kata kalimat tanya parsial dengan kata tanya 'mae' (apa), 'hapo' (siapa), 'kalo' (kapan), 'kekmano' (dimana), 'keno mae' (kenapa), 'gano' (bagaimana) memiliki dua representasi sintaksis, namun tergantung dengan posisi mereka dalam kalimat tersebut. Representasi pertama adalah sebagai specifier, bila di letakkan di posisi depan. Representasi kedua adalah sebagai complemen, jika di letakkan di posisi terakhir. Untuk kalimat tanya total, kata pertanyaan dengan menambahkan akhiran -kah seperti benarkah, sudahkah, dan 
Kalimat tanya parsial $\longrightarrow\left\{\begin{array}{c}\mathrm{SPES} \\ \mathrm{NP}\end{array}\right\}+\left\{\begin{array}{c}\mathrm{C} \\ \mathrm{NP} / \mathrm{PP}\end{array}\right\}+\left\{\begin{array}{c}\mathrm{ADV} \\ \mathrm{NP} / \mathrm{PP}\end{array}\right\}$
Kalimat tanya total $\longrightarrow\left\{\begin{array}{c}\mathrm{C} \\ \mathrm{AUX}\end{array}\right\}+\left\{\begin{array}{c}\mathrm{SPES} \\ \mathrm{NP}\end{array}\right\}+\left\{\begin{array}{c}\mathrm{ADV} \\ \mathrm{NP} / \mathrm{PP}\end{array}\right\}$

lainya, memiliki satu representasi sintaksis, yaitu sebagai complemen.

Sebagai hasil akhir, dapat diambil satu kesimpulan untuk aturan dalam kalimat tanya (interogatif) dalam bahasa Melayu dialek Tamiang adalah sebagai berikut:

\section{UCAPAN TERIMAKASIH}

Alhamdulillah rasa syukur diucapkan kepada Allah SWT yang masih memberikan kesehatan dalam menyelesaikan artikel ini, selanjutnya terima kasih disampaikan pula kepada kedua orang tua Abdul Hafiz dan Sumarni serta kepada dosen pembimbing Dr. Mulyadi, M. Hum, teman-teman sejawat yang telah membimbing dan membantu dalam merampungkan penelitian dan penulisan ini sehingga terwujudlah satu karya dalam bentuk artikel. Artikel. Ucapan terimakasih disampaikan pula pada reviewer dan redaksi yang telah membaca, mengoreksi, dan memberikan masukan terhadap artikel ini. Semoga keikhlasan para dosen, temanteman sejawat dibalas oleh Allah SWT. Amin.

\section{DAFTAR PUSTAKA}

Aprilliyanti. 2014. "Analisis Kalimat Interogatif pada Novel Garuda Putih Karya Suparto Brata" Jurnal Program Studi Pendidikan Bahasa dan Sastra Jawa Vol. /05/No. 01/Agus-

tus 2014. Universitas Muhammadiyah Purworejo.

Astuty, Novy Ary. 2015. "Kalimat Interogatif Bahasa Melayu Dialek Langkat" Skripsi.Medan: Fakultas Ilmu Budaya Universitas Sumatera Utara.

Chaer, Abdul. 2011. Tata Bahasa Praktis Bahasa Indonesia. Jakarta: Rineka Cipta.

Cheung, C. C. H. (2013). "Wh-fronting and the left periphery in Mandarin". Journal of East Asian Linguistics.

Culicover, P.W. 1997. Principtes and Paramaters: An tntroduction to Syntactic Theory. Oxford: Oxford University Press.

Haegemen, L. 1 992. Introduction to Government and Binding Theory. Oxford: Btackwetl.

Keraf, G. 1991. Tata Bahasa Rujukan Bahasa Indonesia. Jakarta: Gramedia.

Kridalaksana, H. 1994. Kelas Kata dalam Bahasa Indonesia. Jakarta: PT. Gramedia Pustaka Utama.

Moleong, Lexy J.. 2014. Metodologi Penelitian Kualitatif, Bandung : PT. Remaja Rosdakarya.

Mulyadi. 2010. "Frasa Preposisi Bahasa Indonesia : Analisis X-Bar". Jurnal kajian sastra. Vol.34 No. 1 -Januari 2010. Medan: Universitas Sumatera Utara.

Pangi, Yunansi. 2014. "Kalimat Tanya Dalam Bahasa Inggris Dan Bahasa 
Loloda Suatu Analisis Kontrastif". Skripsi. Manado: Universitas Sam Ratulangi Fakultas Ilmu Budaya.

Sudaryanto. 2015. Metode dan Aneka Teknik Analisis Bahasa, pengantar penelitian wahana kebudayaan secara linguistik. Yogyakarta: Senata dharma University press.
Sulaiman, B. dkk. (1993). Tata Bahasa Tamiang. Jakarta: Pusat Pembinaandan pengembangan Bahasa Departemena Pendidikan dan kebudayaan. 